\title{
A thermostable laccase from Thermus sp. 2.9 and its potential for delignification of Eucalyptus biomass
}

\author{
Laura E. Navas ${ }^{1,6}$, Fernando D. Martínez ${ }^{1}$, María E. Taverna 2,3,6, Morgan M. Fetherolf ${ }^{4}$, Lindsay D. Eltis ${ }^{4}$, \\ Verónica Nicolau ${ }^{3,6}$, Diana Estenoz ${ }^{2,6}$, Eleonora Campos ${ }^{5,6}$, Graciela B. Benintende ${ }^{1}$ and Marcelo F. Berretta ${ }^{1,6^{*}}$ (D)
}

\begin{abstract}
Laccases are multicopper oxidases that are being studied for their potential application in pretreatment strategies of lignocellulosic feedstocks for bioethanol production. Here, we report the expression and characterization of a predicted laccase (LAC_2.9) from the thermophilic bacterial strain Thermus sp. 2.9 and investigate its capacity to delignify lignocellulosic biomass. The purified enzyme displayed a blue color typical of laccases, showed strict copper dependence and retained $80 \%$ of its activity after $16 \mathrm{~h}$ at $70{ }^{\circ} \mathrm{C}$. At $60^{\circ} \mathrm{C}$, the enzyme oxidized 2, $2^{\prime}$-azino-di-(3-ethylbenzthiazoline sulfonate) (ABTS) and 2,6-dimethoxyphenol (DMP) at optimal pH of 5 and 6, respectively. LAC_2.9 had higher substrate specificity $\left(k_{\mathrm{cat}} / K_{\mathrm{M}}\right)$ for DMP with a calculated value that accounts for one of the highest reported for laccases. Further, the enzyme oxidized a phenolic lignin model dimer. The incubation of steam-exploded eucalyptus biomass with LAC_2.9 and 1-hydroxybenzotriazole (HBT) as mediator changed the structural properties of the lignocellulose as evidenced by Fourier transform infrared (FTIR) spectroscopy and thermo-gravimetric analysis (TGA). However, this did not increase the yield of sugars released by enzymatic saccharification. In conclusion, LAC_2.9 is a thermostable laccase with potential application in the delignification of lignocellulosic biomass.
\end{abstract}

Keywords: Delignification, Eucalyptus globulus biomass, Redox mediator, Thermostable bacterial laccase, Thermus

\section{Introduction}

Laccases (EC 1.10.3.2, benzenediol:oxygen oxidoreductase) are multicopper oxidases (MCO) that catalyze the oxidation of a variety of phenolic and non-phenolic compounds with the concomitant reduction of molecular oxygen to water (Thurston 2019). These enzymes are widely distributed in nature, occurring in plants, insects, fungi and bacteria (Bertrand et al. 2017). Laccases typically comprise three domains and contain four copper ions arranged in mononuclear and trinuclear clusters: substrate oxidation at the mononuclear site generates electrons that are transferred to the trinuclear site where $\mathrm{O}_{2}$ is reduced (Thurston 2019). Due to their low substrate

\footnotetext{
*Correspondence: berretta.marcelo@inta.gob.ar

1 Instituto de Microbiología y Zoología Agrícola, Instituto Nacional de Tecnología Agropecuaria (INTA), Nicolás Repetto y De los Reseros s/n., 1686 Hurlingham, Buenos Aires, Argentina

Full list of author information is available at the end of the article
}

specificity and high oxidative activity, they have been used in a broad spectrum of applications including pulp bleaching in the paper industry and the degradation of dyes in textile effluents (Singh et al. 2011). Since laccases can catalyze the depolymerization of lignin, a recalcitrant polymer, one application of burgeoning interest is in the pretreatment of lignocellulosic biomass for improving enzymatic conversion of cellulose and hemicellulose to fermentable carbohydrates for production of second generation bioethanol (Christopher et al. 2014). The catalytic efficiency of laccases is usually enhanced by small molecules, called mediators, which act as electron carriers between the laccase active site and the substrate structure. Although several natural and synthetic compounds have been identified as mediators, one of the most effective for lignin transformation is 1-hydroxybenzotriazole (HBT) (Christopher et al. 2014; Hilgers et al. 2018). 
The most studied and widely used laccases to date are those from wood decay white-rot fungi (Baldrian 2006). However, bacterial laccases possess a variety of attractive characteristics as compared to fungal laccases, especially with respect to $\mathrm{pH}$-range of activity, thermal stability and resistance to chlorides (Chauhan et al. 2017). In addition, laccases from extremophiles have garnered attention for industrial processes that require harsh conditions, with a few reports of laccases isolated from thermophilic bacteria (Al-kahem Al-balawi et al. 2017; Basheer et al. 2017; Fernandes et al. 2007). Indeed, enzymes from different strains of Thermus thermophilus have been found to be useful for the bleaching of wheat straw pulp (Zheng et al. 2012) and the decolorization of dyes (Kumari et al. 2018; Liu et al. 2015). We have previously isolated a thermophilic bacterial strain, Thermus sp. 2.9, from a hot spring of Argentina (Navas et al. 2014). Among 2719 proteincoding genes predicted from the bacterium's genome sequence (Navas et al. 2015), we identified a gene designated lac_2.9 that encodes a protein with amino acid sequence similarity to laccases.

In this work, we produced and characterized a recombinant form of LAC_2.9. We investigated the enzyme's thermostability, specificity for laccase substrates and its ability to transform lignin model compounds. Finally, we studied the ability of LAC_2.9 to modify Eucalyptus globulus biomass using Fourier transform infrared (FTIR) spectroscopy and thermogravimetric analysis (TGA), and analyzed the effect of pretreating the biomass with LAC_2.9 on the enzymatic hydrolysis of cellulose. The results are discussed with respect to other laccases.

\section{Materials and methods}

\section{LAC_2.9 sequence analysis}

Amino acid sequences were aligned using ClustalX software (https://www.ebi.ac.uk/Tools/msa/clustalw2/). LAC_2.9 domain prediction and analysis were performed using InterProScan (https://www.ebi.ac.uk/interpro/inter proscan.html) and SMART (Simple Modular Architecture Research Tool; http://smart.embl-heidelberg.de/). LipoP (http://www.cbs.dtu.dk/services/LipoP/) was used to predict signal peptidase cleavage sites.

\section{Cloning, expression and purification of recombinant LAC_2.9}

DNA from Thermus sp. 2.9 cells was prepared as described previously (Navas et al. 2014). The DNA encoding the mature LAC_2.9 protein with an N-terminal 6xHis tag was amplified from Thermus sp. 2.9 genomic DNA by PCR using primers: $5^{\prime}$-aggccttcatatgcatcatcaccatcaccaccaggcccctttccega- $3^{\prime}$ and $5^{\prime}$-tggtggt-gggtctagattagctcacctccagaat- $3^{\prime}$ (NdeI and $\mathrm{XbaI}$ restriction sites are underlined). The amplicon was cloned into pJexpress
404 (DNA2.0) using engineered NdeI and XbaI restriction sites. The recombinant plasmid was transformed into Escherichia coli XL-1 Blue MRF' cells by electroporation, and a recombinant clone was verified by sequencing. Expression of lac_2.9 was induced by adding IPTG ( $1 \mathrm{mM}$ final) to the LB medium when the culture reached an $\mathrm{OD}_{600}$ of 0.8 and $\mathrm{CuSO}_{4}$ was added to a final concentration of $0.5 \mathrm{mM}$. After a further incubation for $6 \mathrm{~h}$ at $37{ }^{\circ} \mathrm{C}$, the cells were harvested and lysed in the presence of $1 \mathrm{mM} \mathrm{CuSO}_{4}$. The soluble LAC_2.9 was purified using a Ni-NTA affinity column following the manufacturer's instructions. The eluted fractions containing the recombinant protein were pooled and equilibrated with PBS either by dialysis or size-exclusion chromatography. Protein samples were analyzed using 12\% SDS-PAGE and stored at $-70{ }^{\circ} \mathrm{C}$.

\section{Protein characterization}

Protein concentrations were determined using the Pierce $^{\mathrm{TM}}$ BCA Protein Assay Kit (Thermo Fisher Scientific, Waltham, MA, USA) with bovine serum albumin as a standard. The copper content of LAC_2.9 was determined using 2,2'-bicinchoninic acid (BCA) after reduction of copper ions released from the holoenzyme (Brenner and Harris 1995).

\section{Kinetic assays}

The activity of LAC_2.9 was detected colorimetrically through the oxidation of ABTS (2,2'-azinodi-[3-ethylbenzthiazoline sulfonate]) and DMP (2,6-dimethoxyphenol) by measuring the absorbance at $436 \mathrm{~nm}\left(\varepsilon=36,000 \mathrm{M}^{-1} \mathrm{~cm}^{-1}\right)$ and $468 \mathrm{~nm}$ $\left(\varepsilon=49,600 \mathrm{M}^{-1} \mathrm{~cm}^{-1}\right)$, respectively. Standard assays were performed at $60{ }^{\circ} \mathrm{C}$ and contained $1 \mathrm{mM} \mathrm{CuSO}_{4}$ and either $3 \mathrm{mM}$ ABTS (20 mM sodium acetate, $\mathrm{pH} 5$ ) or $1 \mathrm{mM}$ DMP (20 mM sodium phosphate, $\mathrm{pH}$ ). The dependence of the enzyme activity on copper was evaluated using $0.1-5000 \mu \mathrm{M} \mathrm{CuSO}_{4}$ in the DMP assay. The optimal $\mathrm{pH}$ for each substrate was evaluated over a range between $\mathrm{pH} 3$ and 8 using $20 \mathrm{mM}$ sodium acetate (pH 3-5) and $20 \mathrm{mM}$ sodium phosphate (pH 6-8) buffers. The thermostability of the enzyme was analyzed by measuring the residual activity on ABTS at $\mathrm{pH} 5$, after incubating the enzyme at 60,70 and $80{ }^{\circ} \mathrm{C}$ for 2,6 and $16 \mathrm{~h}$. The laccase activity was calculated as the enzymatic units (U) per ml, with $1 \mathrm{U}$ being the amount of enzyme needed to oxidize $1 \mu \mathrm{mol}$ of ABTS in $1 \mathrm{~min}$. The effect of $1 \mathrm{mM} \mathrm{Mg}{ }^{2+}, \mathrm{Mn}^{2+}, \mathrm{Zn}^{2+}, \mathrm{Ca}^{2+}$, sodium dodecyl sulfate (SDS), ethylenediaminetetraacetic acid (EDTA), dithiothreitol (DTT) and 1-100 mM NaCl on LAC_2.9 activity was assayed by incubating the enzyme with each effector in the reaction mix prior to the addition of ABTS, after which the reaction was carried out as described 
previously. The enzyme activity in a control reaction without effector was set to $100 \%$. All measurements were carried out in triplicate.

Steady-state kinetic parameters were evaluated at $60^{\circ} \mathrm{C}$ using different concentrations of ABTS $(50-6000 \mu \mathrm{M})$ in $20 \mathrm{mM}$ sodium acetate, $\mathrm{pH} 5$ and DMP $(0.2-1500 \mu \mathrm{M})$ at $20 \mathrm{mM}$ sodium phosphate, $\mathrm{pH}$ 6. Reaction mixtures also contained $1 \mathrm{mM} \mathrm{CuSO}_{4}$. Steady-state rate equations were fitted to data using the least-squares and dynamicweighting options of the program LEONORA (CornishBowden 1995). Curves of initial velocity vs. substrate concentration were plotted using Origin software (Deschenes and Vanden Bout 2000).

\section{Transformation of lignin model compounds}

The ability of LAC_2.9 to transform guaiacylglycerol$\beta$-guaiacyl ether and veratrylglycerol- $\beta$-guaiacyl ether was performed essentially as described by Brown et al. (2012). Briefly, $1 \mathrm{mM}$ of lignin model compound (LMC) was incubated with $0.2 \mu \mathrm{M}$ LAC_2.9 in $20 \mathrm{mM}$ sodium phosphate, $\mathrm{pH} 6$ containing $1 \mathrm{mM} \mathrm{CuSO}$. The reactions were incubated at $60^{\circ} \mathrm{C}$ with stirring and quenched after 30 min or $6 \mathrm{~h}$ by adding acetic acid to $0.5 \%$ final concentration. The quenched reaction was centrifuged at $16,000 \times g$ for $5 \mathrm{~min}$, and the cleared solution was analyzed by reverse-phase HPLC. Samples were analyzed using a Waters 2695 HPLC (Waters, Milford, MA, USA) equipped with a Luna ${ }^{\circledR} 5 \mu \mathrm{m} \mathrm{C18(2)} \mathrm{column}$ $250 \times 4.6 \mathrm{~mm}$ (Phenomenex, Torrance, CA, USA) and a

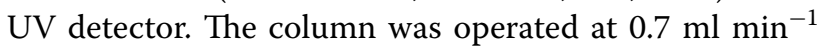
and the sample was eluted using a $16.8 \mathrm{ml}$ linear gradient of $1 \%$ formic acid in $\mathrm{H}_{2} \mathrm{O}$ to $100 \%$ methanol.

\section{Enzymatic pretreatment of lignocellulosic biomass with LAC_2.9}

The lignocellulosic biomass used was the washed, water insoluble (WIS) fraction of E. globulus pretreated by steam explosion (conditions: $187.8{ }^{\circ} \mathrm{C}, 16 \mathrm{~min}$ ). The relative composition of the steam exploded biomass was: cellulose $62.89 \pm 0.81$; hemicellulose $4.74 \pm 0.08$; acid insoluble lignin $31.46 \pm 2.29$; ashes 0.55 . The biomass, and the determination of its composition, were provided by Dr. Mercedes Ballesteros, from Unidad de Biocarburantes, Centro de Investigaciones Energéticas, Medioambientales y Tecnológicas (CIEMAT), Madrid, Spain. Samples of biomass $(20 \mathrm{mg})$ were treated with laccase in $1 \mathrm{ml}$ reactions containing $50 \mathrm{mM}$ sodium acetate, $\mathrm{pH}$ $5,1 \mathrm{mM} \mathrm{CuSO}_{4}$, and $1 \mathrm{U}$ of LAC_2.9, in the presence or absence of $1.5 \mathrm{mM}$ HBT or $p \mathrm{HBA}$ (para-hydroxybenzoic acid). In blank treatments laccase was replaced by crude extract of soluble proteins from $E$. coli transformed with the empty expression vector, with or without mediators. Samples were incubated at $120 \mathrm{rpm}$ and $60{ }^{\circ} \mathrm{C}$ for $24 \mathrm{~h}$.
The solid residue obtained by centrifugation was washed with distilled water and analyzed by FTIR and TGA after being air-dried for 3 days at $50{ }^{\circ} \mathrm{C}$.

Alternatively, the dried samples of biomass treated with LAC_2.9 (and no-enzyme controls) were submitted to an alkaline peroxide extraction in which they were incubated with $1 \%(\mathrm{w} / \mathrm{w}) \mathrm{NaOH}$ and $3 \%(\mathrm{w} / \mathrm{w}) \mathrm{H}_{2} \mathrm{O}_{2}$ (with respect to sample dry weight) at $80{ }^{\circ} \mathrm{C}$ for $90 \mathrm{~min}$ (Babot et al. 2011).

\section{Analysis of biomass}

FTIR spectra were recorded using a Shimadzu FTIR8201 PC spectrometer (SSI, Kyoto, Japan). Samples were molded into discs of $\mathrm{KBr}$ and spectra were recorded from 400 to $2000 \mathrm{~cm}^{-1}$ at a resolution of $2 \mathrm{~cm}^{-1}$. Hyper IR software was used to analyze spectra. TGA measurements were conducted using a TA2000 Thermal Analysis System (TA Instruments, New Castle, DE, USA) under pyrolytic conditions. Thermograms were recorded from 20 up to $700{ }^{\circ} \mathrm{C}$ at rate of $10{ }^{\circ} \mathrm{C} \mathrm{min}{ }^{-1}$ using $\sim 2 \mathrm{mg}$ of sample.

\section{Saccharification of woody biomass}

Samples of biomass treated with LAC_2.9 and extracted wih alkaline peroxide were washed with water and the solids were incubated with a cellulase cocktail $\left(\right.$ Cellic $^{\circledR}$ CTec2, Novozymes, Bagsværd, Denmark; 0.5 filter paper units per gram of biomass) in $1 \mathrm{ml} 50 \mathrm{mM}$ sodium acetate, $\mathrm{pH} 5.5$ for $16 \mathrm{~h}$ at $50{ }^{\circ} \mathrm{C}$. The supernatant was recovered by centrifugation and the reducing sugars were quantified using dinitrosalicylic acid (DNS) (Miller 1959). Data from biological and technical replicates were averaged.

\section{Results}

Sequence analysis of LAC_2.9

Analysis of the Thermus sp. 2.9 genome (Navas et al. 2015) revealed a gene encoding a putative MCO (GenBank accession no. KHG66454.1). The 467 amino acid protein, referred to herein as LAC_2.9, shared 98\% sequence identity with a predicted $\mathrm{MCO}$ from $T$. thermophilus JL-18 (accession no. AFH38224.1). In silico analysis of LAC_2.9 predicted the occurrence of the three conserved domains typical of this class of MCOs as well as four copper-binding motifs, consistent with mononuclear and trinuclear copper centers (Reiss et al. 2013). Comparison with the laccases from Thermus characterized to date showed that LAC_2.9 shares 73\% sequence identity with Tth-laccase of T. thermophilus HB27 (Miyazaki 2005) and 97\% identity with LacTT from $T$. thermophilus SG0.5JP17-16 (Liu et al. 2015) (Additional file 1: Figure S1). A signal peptide cleavage site was predicted between residues 23 and 24 of LAC_2.9, such that 
the mature polypeptide was predicted to have 444 amino acids and a molecular mass of $49.5 \mathrm{kDa}$.

\section{Catalytic properties of recombinant LAC_2.9}

To characterize LAC_2.9, the gene encoding the mature protein was cloned and expressed in E. coli as an N-terminally His-tagged protein. To maximize specific activity, $\mathrm{CuSO}_{4}$ was added to the culture medium at the time of induction and to the lysis buffer. LAC_2.9 was purified by affinity chromatography using Ni-NTA resin. The purified protein exhibited the blue color typical of laccases and had a molecular mass of $\sim 49 \mathrm{kDa}$ as judged by SDS-PAGE (Fig. 1). Indeed, the protein has an absorption centered at $621 \mathrm{~nm}$, indicative of a T1 blue copper site. Purified LAC_2.9 had a molar copper content of $4.09 \mathrm{Cu}$, indicating that the protein was loaded with a full complement of copper.

Despite containing a full complement of copper, LAC_2.9 requires additional copper ion for activity (Fig. 2a). The dependence of the activity on $\mathrm{Cu}^{2+}$ concentration was sigmoidal. Similar behavior has been documented in other bacterial laccases (Basheer et al. 2017; Kim et al. 2015; Miyazaki 2005), with some authors suggesting the existence of an extra copper binding site that is essential for activity. Subsequent kinetic

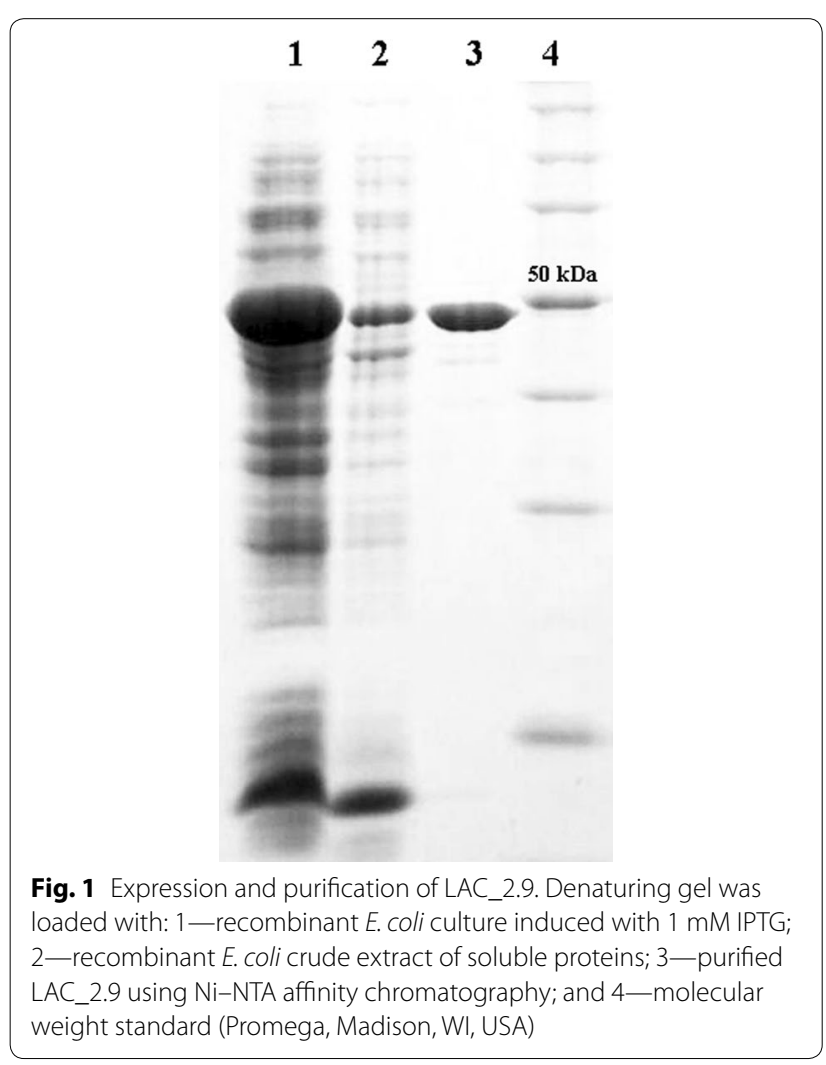

characterization was performed using assay buffers containing $1 \mathrm{mM} \mathrm{CuSO}_{4}$.

LAC_2.9 utilized both ABTS and DMP as reducing substrates. However, the $\mathrm{pH}$ optimum depended on the substrate: 5.0 and 6.0 for ABTS and DMP, respectively (Fig. 2b). This is similar to what has been reported for other bacterial laccases (Berini et al. 2018). The thermal stability of LAC_2.9 was evaluated by incubating the enzyme for up to $16 \mathrm{~h}$ at $60^{\circ} \mathrm{C}, 70{ }^{\circ} \mathrm{C}$ and $80^{\circ} \mathrm{C}$, and measuring the residual activity (Fig. $2 \mathrm{c}$ ). At $60^{\circ} \mathrm{C}$, LAC_2.9 showed no discernable loss of activity after $16 \mathrm{~h}$. By contrast, $80 \%$ of the activity remained after $16 \mathrm{~h}$ at $70{ }^{\circ} \mathrm{C}$ and after $6 \mathrm{~h}$ at $80^{\circ} \mathrm{C}$. Based on this result, subsequent experiments were performed at $60^{\circ} \mathrm{C}$. More generally, this stability indicates that the enzyme is sufficiently robust for industrial applications.

We also investigated the effect of metal ions, EDTA, DTT, SDS detergent and $\mathrm{NaCl}$ on the activity of LAC_2.9. Each of these reagents was tested at a concentration of $1 \mathrm{mM}$ (Fig. 2d) and $\mathrm{NaCl}$ also at 10 and $100 \mathrm{mM}$. With respect to metal ions, LAC_2.9 was more resistant than LacTT. In contrast, LacT T was more resistant to SDS and $\mathrm{NaCl}$ (Liu et al. 2015). Finally, LAC_2.9 was sensitive to EDTA, a common characteristic of laccases that depend on additional $\mathrm{Cu}^{2+}$ for activity (Kim et al. 2015; Miyazaki 2005).

\section{Steady-state kinetic parameters}

The steady-state kinetic parameters of LAC_2.9 were evaluated for ABTS and DMP at $\mathrm{pH} 5.0$ and 6.0, respectively. The enzyme followed Michaelis-Menten behavior for both substrates (Additional file 1: Figure S2). LAC_2.9 had $>50$-fold higher substrate specificity ( $k_{\text {cat }}$ ' $K_{\mathrm{m}}$ ) for DMP than for ABTS at their respective optimal pH (Table 1). Furthermore, this specificity for DMP was > threefold higher than that reported for T. thermophilus laccases (Table 1), and in general, for most bacterial laccases, although the specificity of bacterial laccases against DMP is generally lower than that of fungal laccases (Additional file 1: Table S1). By contrast, the specificity of LAC_2.9 for ABTS is among the lowest reported for laccases from $T$. thermophilus strains. Finally, despite the high amino acid sequence identity between LAC_2.9 and LacTT from T. thermophilus SG0.5JP17-16 (Liu et al. 2015), their respective substrate specificities are quite different, with LacTT having a higher substrate specificity for ABTS than for DMP.

\section{Reactivity towards lignin model compounds}

Due to the complexity of native lignin, model compounds have been used to study the ability of laccases and peroxidases to transform lignin structures. Since $\beta-O-4$ linkages represent the majority of linkages between 

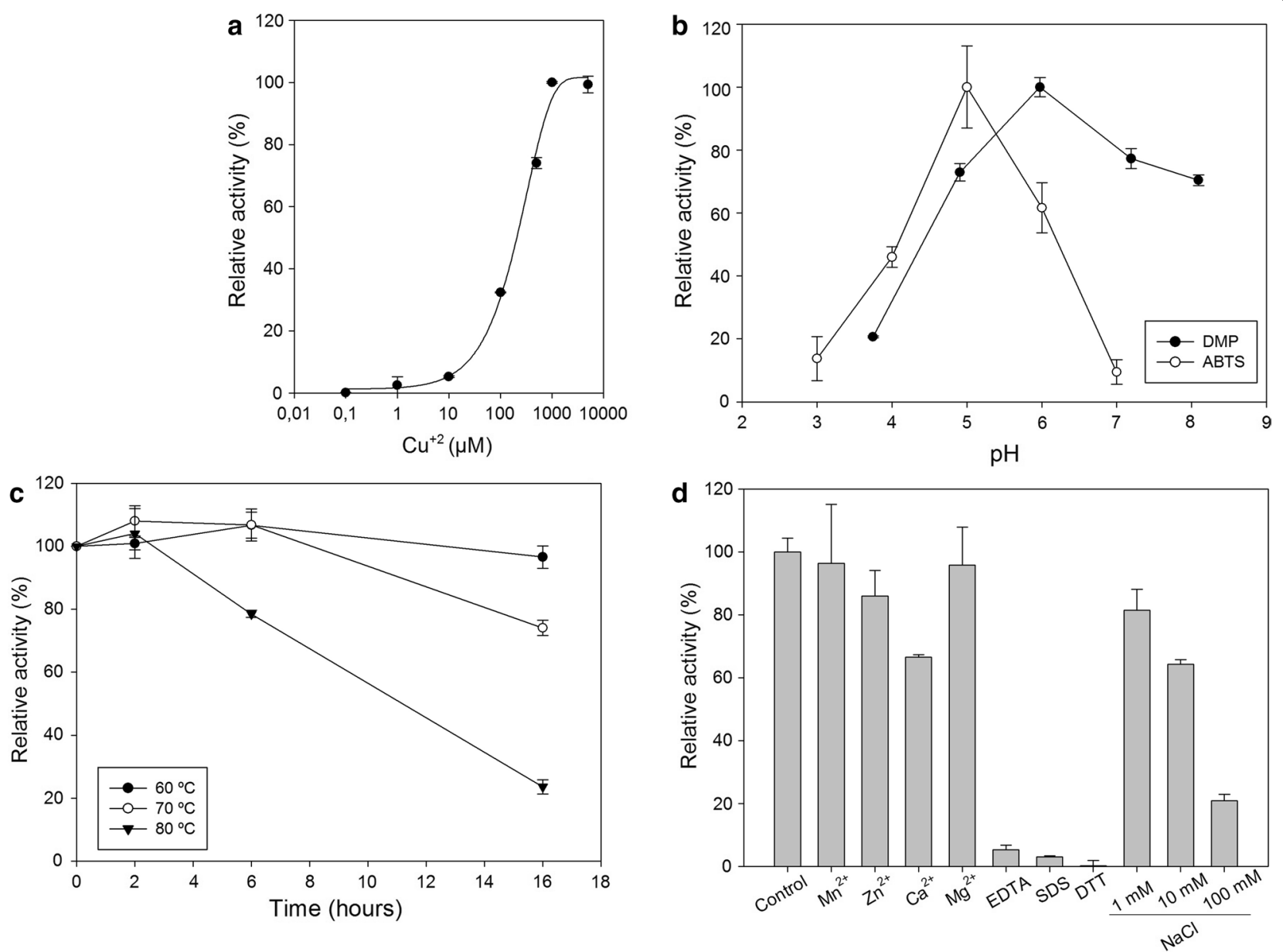

Fig. 2 Dependence of LAC_2.9 activity on reaction conditions. a Copper dependence of activity; $\mathbf{b}$ pH dependence of activity; $\mathbf{c}$ thermal stability profile obtained measuring the residual activity on ABTS at $60^{\circ} \mathrm{C}$, after incubating the enzyme at 60,70 and $80^{\circ} \mathrm{C}$ up to $16 \mathrm{~h}$; $\mathbf{d}$ effect of metal ions, SDS, EDTA, DTT (1 mM of each) and $\mathrm{NaCl}(1-100 \mathrm{mM}$ ). Assays were carried out in triplicate. The bars indicate standard deviation

Table 1 Comparison of the steady-state kinetic parameters of LAC_2.9 with those of laccases from Thermus thermophilus strains

\begin{tabular}{|c|c|c|c|c|c|c|}
\hline & \multicolumn{3}{|l|}{ ABTS } & \multicolumn{3}{|l|}{ DMP } \\
\hline & $K_{m}(\mathrm{mM})$ & $k_{c a t}\left(\mathrm{~s}^{-1}\right)$ & $k_{c a t} / K_{m}\left(\mathrm{mM}^{-1} \mathrm{~s}^{-1}\right)$ & $K_{m}(\mathrm{mM})$ & $k_{\text {cat }}\left(\mathrm{s}^{-1}\right)$ & $k_{c a t} / K_{m}\left(\mathrm{mM}^{-1} \mathrm{~s}^{-1}\right)$ \\
\hline LAC_2.9 $9^{\mathrm{a}}$ & $0.59 \pm 0.08$ & $1.00 \pm 0.04$ & $1.7 \pm 0.2$ & $0.119 \pm 0.006$ & $11.6 \pm 0.3$ & $97 \pm 3$ \\
\hline Tth-laccase ${ }^{b}$ & 0.9 & 24.6 & 27.3 & $n a^{f}$ & na & na \\
\hline Tth-laccase ${ }^{c}$ & 2.4 & 4.77 & 1.98 & na & na & na \\
\hline TtSLAC ${ }^{d}$ & 0.49 & 1.48 & 3.02 & 0.11 & 2.9 & 27 \\
\hline LacTT $^{e}$ & $0.036 \pm 0.003$ & $0.37 \pm 0.01$ & $10.13 \pm 0.03$ & $0.15 \pm 0.01$ & $0.13 \pm 0.01$ & $1.00 \pm 0.03$ \\
\hline
\end{tabular}

a Reactions at $60^{\circ} \mathrm{C}$. For ABTS: $20 \mathrm{mM}$ sodium acetate, $\mathrm{pH}$ 5. For DMP: $20 \mathrm{mM}$ sodium phosphate, $\mathrm{pH} 6$

b Miyazaki (2005). Reactions at $90^{\circ} \mathrm{C}$. Buffer information not available

c Kumari et al. (2018). Reactions at $60^{\circ} \mathrm{C}$. Buffer Britton and Robinson, pH 4.5

d Kim et al. (2015). Reactions at $75^{\circ} \mathrm{C}$. For ABTS: $50 \mathrm{mM}$ sodium acetate, pH 4.5. For DMP: buffer information not available

e Liu et al. (2015). Reactions at $90^{\circ} \mathrm{C}$. For ABTS: buffer Britton and Robinson, pH 4.5. For DMP: buffer Britton and Robinson, pH 8

f Not available 
lignin subunits, we tested the reactivity of LAC_2.9 towards guaiacylglycerol- $\beta$-guaiacyl ether (GGE) and veratrylglycerol- $\beta$-guaiacyl ether (VBG), which are phenolic and non-phenolic ethers, respectively. Upon incubation with LAC_2.9, the peak corresponding to GGE decreased with time, and two new peaks appeared later (Fig. 3). In contrast, the peak of VBG remained unchanged after treatment. These results indicate that LAC_2.9 is able to transform the phenolic substrate in the absence of mediators. The retention time of the GGE oxidation products suggests that they are oligomerization products as reported by Hilgers et al. (2018). Overall, it appears that under our experimental conditions, LAC_2.9 catalyzes the oxidative coupling of GGE units, and not the cleavage of the $\beta-O-4$ bond.

\section{Pretreatment with LAC_2.9 and saccharification of woody biomass}

To evaluate the potential of LAC_2.9 for processing lignocellulose, the enzyme was incubated with steamexploded biomass from eucalyptus at $60{ }^{\circ} \mathrm{C}$ for $24 \mathrm{~h}$ in the absence and presence of redox mediators. The enzyme-treated biomass was then analyzed using FTIR spectroscopy to infer structural changes in each of the lignin, cellulose and hemicellulose components using band assignments described by Rodrigues et al. (1998) and Avanthi and Banerjee (2016). Inspection of the spectra revealed that incubation with LAC_2.9 in the absence of mediator induced no differences in the bands at $1500 / 1505$ and $1595 \mathrm{~cm}^{-1}$ ( $\mathrm{C}=\mathrm{C}$ stretching vibration), corresponding to lignin's aromatic backbone, and the band at $1732 \mathrm{~cm}^{-1}$, corresponding to a $\mathrm{C}=\mathrm{O}$ stretching vibration associated with a lignin-hemicellulose linkage (Fig. 4a). However, in samples incubated with the laccase in presence of $\mathrm{HBT}$, a relative decrease in the intensity of the bands at 1500 and $1732 \mathrm{~cm}^{-1}$ was observed (Fig. 4b). In all LAC_2.9-treated samples, the bands arising from cellulose $\left(898 \mathrm{~cm}^{-1}, 1030 \mathrm{~cm}^{-1}, 1050 \mathrm{~cm}^{-1}, 1090 \mathrm{~cm}^{-1}\right.$, $1150 \mathrm{~cm}^{-1}$, and $1240 \mathrm{~cm}^{-1}$ ) were slightly more intense as compared to no-enzyme controls. This increase in intensity was more pronounced when mediators were also included, especially for the bands at $1030 \mathrm{~cm}^{-1}$, $1050 \mathrm{~cm}^{-1}$ and $1090 \mathrm{~cm}^{-1}$ (Fig. 4b, c). Similar changes in FTIR spectra have been associated with the delignification of lignocellulosic biomass (Avanthi and Banerjee 2016).

To further evaluate the effect of LAC_2.9 on woody biomass, we investigated the thermal degradation profile of the enzyme-treated samples. Under pyrolytic conditions in an inert atmosphere, the eucalyptus exhibited a single mass loss step due primarily to the volatilization of cellulose and hemicelluloses (Fig. 5), leaving a carbonaceous residue (char) which mainly results from the lignin (Vila et al. 2011). Inspection of the thermogram (Fig. 5a) indicates that LAC_2.9-treatment did not affect the percentage of char $(28 \%)$ as compared to a no-enzyme
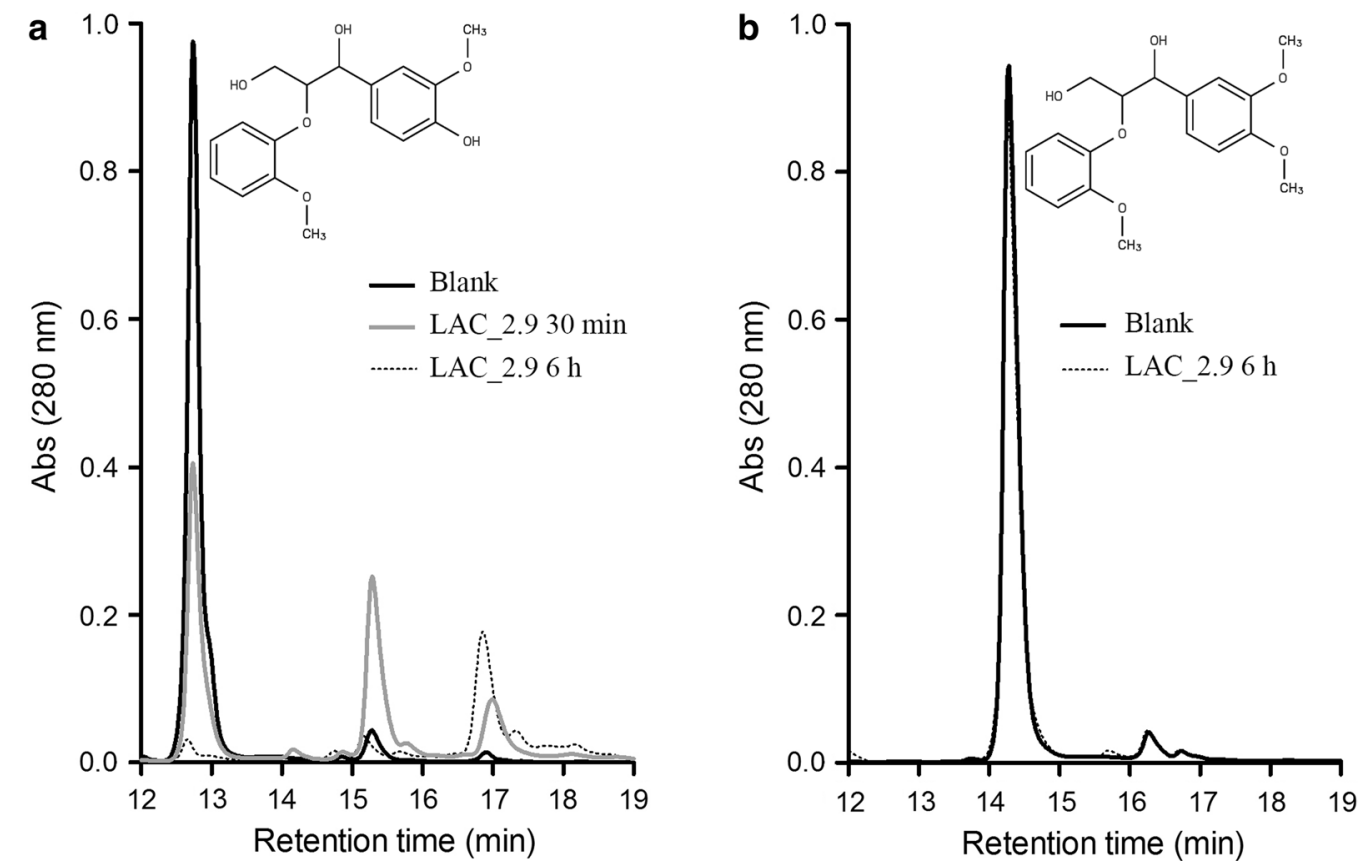

Fig. 3 Reactivity of $L A C \_2.9$ with $\beta-0-4$ biaryl ethers. HPLC traces of reactions performed with a guaiacylglycerol- $\beta$-guaiacyl ether and $\mathbf{b}$ veratrylglycerol- $\beta$-guaiacyl ether. Reactions were incubated at $60{ }^{\circ} \mathrm{C}$ for $30 \mathrm{~min}$ and/or $6 \mathrm{~h}$ 

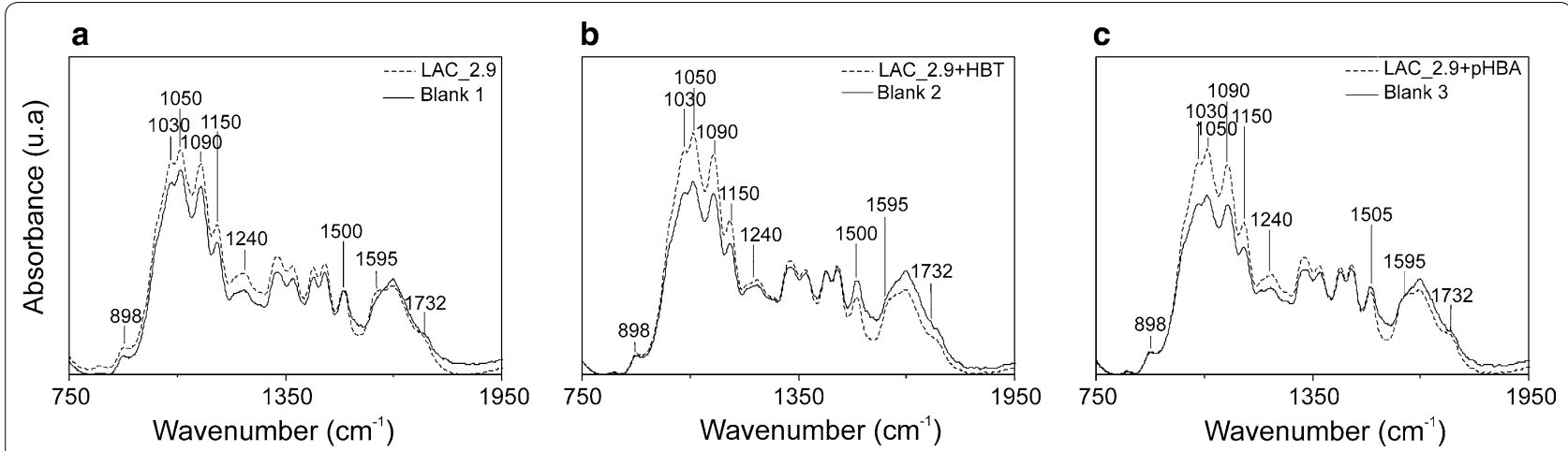

Fig. 4 FTIR spectra of LAC_2.9-treated eucalyptus biomass. Samples were treated with: a LAC_2.9; b LAC_2.9 and HBT; and $\mathbf{c} L A C \_2.9$ with $p H B A$. Dotted lines represent spectra of enzyme-treated samples. Solid lines represent spectra of equivalent no-enzyme controls treated with cellular extract of E. coli

control. However, the addition of mediators with the enzyme resulted in a residual mass decrease of 4 percentage points for HBT (Fig. $5 \mathrm{~b}$ ) and 8 percentage points for $p$ HBA (Fig. 5c), which suggests the partial removal of lignin. As illustrated by the first derivative of the thermograms (Fig. 5a', b' and $\mathrm{c}^{\prime}$ ), all LAC_2.9 treatments increased the temperature of thermal decomposition in comparison to no-enzyme controls. This is observed as a shift to higher temperatures for the maximum rate of weight loss: $6{ }^{\circ} \mathrm{C}$ for laccase alone, $11{ }^{\circ} \mathrm{C}$ for laccase with $\mathrm{HBT}$ and $7{ }^{\circ} \mathrm{C}$ for laccase with $p \mathrm{HBA}$. Additionally, the ratio of maximum rates of weight loss in laccase treatments versus controls is comparatively higher in treatments with mediators. Collectively the modifications observed in the biomass after the treatment with the laccase-mediator systems suggest degradation of lignin and hemicelluloses adhered to cellulose. These results mirror what has been reported for the treatment of cypress biomass with a fungal laccase (Moniruzzaman et al. 2015) and for the laccase-mediator treatment of flax pulp (Vila et al. 2011). Based on X-ray diffraction, Avanthi and Banerjee (2016) further reported that treatment of lignocellulosic biomass with laccase results in a more ordered arrangement of cellulose after.

To evaluate whether the LAC_2.9-induced changes in the woody biomass correlated with an improvement of the saccharification of residual cellulose and hemicellulose fractions, samples were extracted once with alkaline hydrogen peroxide and then hydrolyzed with a cellulase cocktail, and the release of reducing sugars was measured. None of the laccase treatments, with or without mediators, resulted in significant differences in the yield of released sugars (Additional file 1: Table S2). This suggests that in our experimental conditions, the changes detected in the biomass by spectroscopic and thermal analyses after laccase and laccase-HBT system treatments did not render cellulose and hemicellulose more accessible to enzymatic attack.

\section{Discussion}

Laccases have gained interest for application in several industrial fields and enzymatic bioremediation (Singh et al. 2011). Due to their capacity to modify lignin they have potential for being integrated in emerging biorefineries for the production of lignocellulose-derived ethanol and the conversion of lignin into products of higher value (Fillat et al. 2017). Enzymes best suited for such applications should be highly stable at adverse operational conditions. In this sense, bacterial laccases have comparative advantages with respect to fungal laccases (Chauhan et al. 2017). Since the production of these enzymes from their native sources is usually low, their expression in heterologous hosts may provide the required level of production to fulfill the commercial demand.

In this work we have cloned and expressed in E. coli LAC_2.9, a laccase from the thermophilic bacterial strain Thermus sp. 2.9. We studied the catalytic properties of the enzyme towards typical laccase substrates and assessed its ability to enhance the enzymatic saccharification of woody biomass.

The amino acid sequence of LAC_2.9 reveals the presence of 3 domains and shares high identity with two previously characterized enzymes from different strains of T. thermophilus, Tth-laccase (Miyazaki 2005) and LacTT (Liu et al. 2015). Another laccase from T. thermophilus was characterized by Kim et al. (2015); this enzyme is a low molecular weight protein, not related in sequence to the previous ones, and has been assigned to a different protein family (Pfam Cu-oxidase_4).

A key factor of successful expression of laccases in heterologous systems consists in obtaining a soluble, properly folded holoenzyme, with a full complement of 

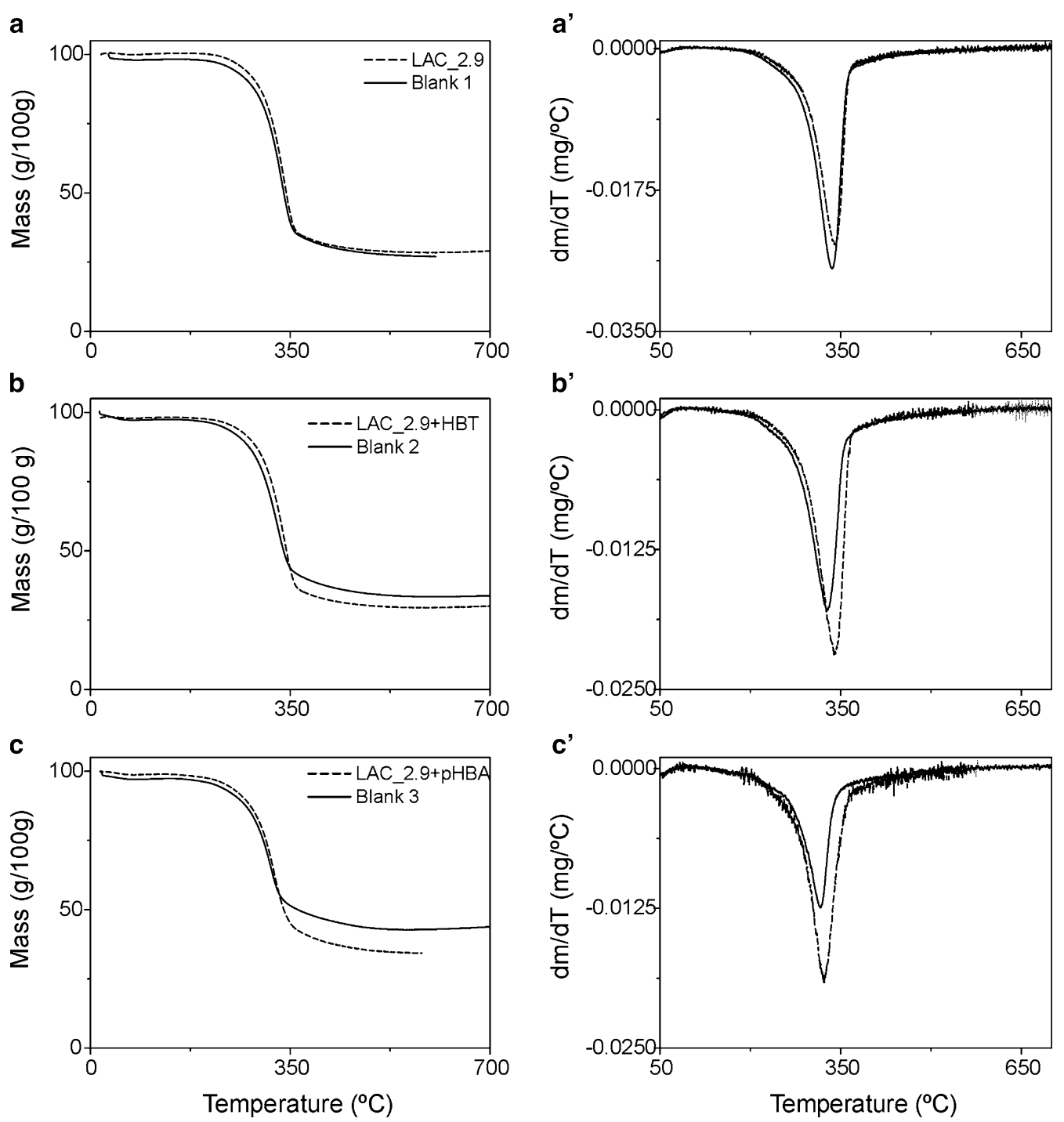

Fig. 5 TGA analysis of LAC_2.9-treated eucalyptus biomass. Thermograms (left) and the first derivative curves (right) of biomass treated with (dotted line) and without (solid line) laccase using: $\mathbf{a}$, a' LAC_2.9; b, b' $\mathbf{b}^{\prime}$ LAC_2.9 with HBT redox mediator; $\mathbf{c}, \mathbf{c}^{\prime}$ LAC_2.9 with pHBA redox mediator. In no-enzyme controls, LAC_2.9 was replaced with cellular extract of E. coli

copper. To this end, it is required to supplement the culture medium with $\mathrm{Cu}$. For E. coli it is known that intracellular $\mathrm{Cu}$ accumulates at higher concentration during oxygen-limited growth (Outten et al. 2001); consequently, under this growing condition, a fully active holoenzyme may be produced, but at the cost of a lowered productivity. Alternatively, as in the case of CotA laccase from Bacillus subtilis, the holoenzyme may also be reconstituted in vitro (Durao et al. 2008). Though, the activity of fully $\mathrm{Cu}$-loaded CotA has been shown to vary depending on whether $\mathrm{Cu}$ was incorporated in vivo or in vitro. To produce LAC_2.9, we supplemented the culture medium with $\mathrm{Cu}$ at the time of induction and continued growing
E. coli under aerobic conditions. Subsequently, cells were lysed in buffer also containing $\mathrm{Cu}$ and the soluble, Histagged protein was purified by Ni-NTA affinity chromatography. With this method we obtained LAC_2.9 with a $\mathrm{Cu}$ content of c.a. $4 \mathrm{~mol} \mathrm{Cu}$ per mol protein, as expected for a complete monomeric holoenzyme. We found that LAC_2.9 also required additional $\mathrm{Cu}^{2+}$ in the reaction for activity. This requirement was observed in other bacterial MCOs, including LAC_2.9 homologs of T. thermophilus (Miyazaki 2005; Liu et al. 2015), and has been associated with the presence of a methionine-rich sequence. Structural analysis by Roberts et al. (2003) revealed the methionines are involved in binding a labile copper ion 
in $\mathrm{CueO}$, an MCO from E. coli. For the McoA enzyme of Aquifex aeolicus it was suggested that the binding of $\mathrm{Cu}^{2+}$ to the methionine-rich region leads to steric changes that facilitates the oxidation of organic substrates (Fernandes et al. 2007).

LAC_2.9 exhibited a remarkable high substrate specificity $\left(k_{\mathrm{cat}} / K_{\mathrm{m}}\right)$ for the phenolic substrate DMP, only comparable to the highest values reported for CotA laccase in a study aimed at identifying experimental conditions conducive to obtaining the fully active recombinant enzyme (Durao et al. 2008). According to this specificity, LAC_2.9 also showed reactivity towards a phenolic lignin model compound (LMC) but not towards a non-phenolic LMC. This reaction appeared to result in the oligomerization of the LMC units. Similar results were reported for experiments using fungal laccases (Hilgers et al. 2018; Ramalingam et al. 2017).

The Tth-laccase from T. thermophilus has been applied to the bleaching of wheat straw pulp with the result that pulp brightness was increased and the residual lignin content was decreased (Zheng et al. 2012). In the present work, we studied the ability of LAC_2.9 to change the structural properties and to improve the hydrolysability of steam-exploded eucalyptus biomass. Using FTIR spectroscopy we found differences in the spectra of samples treated with LAC_2.9-HBT at bands corresponding to functional groups associated with lignin. These modifications may have arisen from delocalization of electrons, induced by the formation of active radicals from the phenolic subunits of lignin, as one of several possible reactive events (Munk et al. 2014). Additionally, TGA data suggested a slight decrease in the relative lignin content of the biomass after being treated with LAC 2.9-HBT. In spite of these results, no increase in the enzymatic conversion to sugar was obtained after saccharification of LAC_2.9-HBT-pretreated biomass with a cellulose cocktail. This result was similar to that obtained by De La Torre et al. (2017) when treating steam-exploded wheat straw with a fungal laccase, although they found a bacterial laccase to improve the hydrolysability of the same material. Other authors have already observed and studied cases where the amount of sugar released was not improved after a laccase treatment. Yu et al. (2014) tested different enzymatic hydrolysis strategies combined with a laccase pretreatment and observed inhibition by active laccases and oxidized HBT. Oliva-Taravilla et al. (2015, 2016) explained the inhibition of the hydrolytic enzymes either by the phenol oligomers formed by laccases or by the adsorption of the enzymes into lignin present in the biomass sample.

Our results warrant further studies to determine the modifications that LAC_2.9 may produce in different lignocellulosic feedstocks and to realize its potential for improving the efficiency of processes for their conversion into added value products.

\section{Additional file}

Additional file 1. Additional tables and figures.

\section{Authors' contributions}

LN obtained and purified the enzyme and performed experiments with the help of FM. MT performed FTIR and TGA analysis. MF and LE advised on experiments of protein characterization, kinetic assays and transformation of LMC. VN and DE assisted with the analysis and discussion of FTIR and TGA results. EC advised on experiments of biomass pretreatment and saccharification. GB advised on the study and helped supervise the project. LN and MB wrote the manuscript with the critical feedback of LE and contributions from all authors. $\mathrm{MB}$ conceived the study and supervised the project. All authors read and approved the final manuscript.

\section{Author details}

${ }^{1}$ Instituto de Microbiología y Zoología Agrícola, Instituto Nacional de Tecnología Agropecuaria (INTA), Nicolás Repetto y De los Reseros s/n., 1686 Hurlingham, Buenos Aires, Argentina. ${ }^{2}$ Instituto de Desarrollo Tecnológico Para la Industria Química, INTEC (UNL-CONICET), Santa Fe, Argentina. ${ }^{3}$ GPol, UTN, Facultad Regional San Francisco, Santa Fe, Argentina. ${ }^{4}$ Department of Microbiology \& Immunology, The University of British Columbia, Vancouver, BC V6T 1Z3, Canada. ${ }^{5}$ Instituto de Biotecnología, Instituto Nacional de Tecnología Agropecuaria (INTA), Hurlingham, Buenos Aires, Argentina. ${ }^{6}$ Consejo Nacional de Investigaciones Científicas y Técnicas (CONICET), CABA, Argentina.

\section{Acknowledgements}

We thank Irma Fuxan for the technical support in routine laboratory protocols. LN and MT were granted fellowships from Consejo Nacional de Investigaciones Científicas y Técnicas (CONICET). VN, DE, EC and MB are staff members of CONICET.

\section{Competing interests}

The authors declare that they have no competing interests.

\section{Availability of data and materials}

The data supporting the conclusions of this article are included within the article and Additional file 1.

\section{Consent for publication}

Not applicable.

\section{Ethics approval and consent to participate}

Not applicable.

\section{Funding}

This work was supported by the Instituto Nacional de Tecnología Agropecuaria (INTA) (Grant Number PNAlyAV-1130034).

\section{Publisher's Note}

Springer Nature remains neutral with regard to jurisdictional claims in published maps and institutional affiliations.

Received: 29 January 2019 Accepted: 4 February 2019

Published online: 12 February 2019

\section{References}

Al-kahem Al-balawi TH, Wood AL, Solis A, Cooper T, Barabote RD (2017) Anoxybacillus sp. strain UARK-01, a new thermophilic soil bacterium with 
hyperthermostable alkaline laccase activity. Curr Microbiol 74:762-771. https://doi.org/10.1007/s00284-017-1239-5

Avanthi A, Banerjee R (2016) A strategic laccase mediated lignin degradation of lignocellulosic feedstocks for ethanol production. Ind Crops Prod 92:174-185. https://doi.org/10.1016/j.indcrop.2016.08.009

Babot ED, Rico A, Rencoret J, Kalum L, Lund H, Romero J, del Río JC, Martínez AT, Gutiérrez A (2011) Towards industrially-feasible delignification and pitch removal by treating paper pulp with Myceliophthora thermophila laccase and a phenolic mediator. Bioresour Technol 102:6717-6722. https ://doi.org/10.1016/j.biortech.2011.03.100

Baldrian P (2006) Fungal laccases-occurrence and properties. FEMS Microbiol Rev 30:215-242. https://doi.org/10.1111/j.1574-4976.2005.00010.x

Basheer S, Rashid N, Ashraf R, Akram MS, Siddiqui MA, Imanaka T, Akhtar M (2017) Identification of a novel copper-activated and halide-tolerant laccase in Geobacillus thermopakistaniensis. Extremophiles 21:563-571. https ://doi.org/10.1007/s00792-017-0925-3

Berini F, Verce M, Ausec L, Rosini E, Tonin F, Pollegioni L, Mandi I (2018) Isolation and characterization of a heterologously expressed bacterial laccase from the anaerobe Geobacter metallireducens. Appl Microbiol Biotechnol 102:2425-2439. https://doi.org/10.1007/s00253-018-8785-z

Bertrand B, Martínez-Morales F, Trejo-Hernández MR (2017) Upgrading laccase production and biochemical properties: strategies and challenges. Biotechnol Prog 33:1015-1034. https://doi.org/10.1002/btpr.2482

Brenner A, Harris E (1995) A quantitative test for copper using bicinchoninic acid. Anal Biochem 226:80-84

Brown ME, Barros T, Chang MCY (2012) Identification and characterization of a multifunctional dye peroxidase from a lignin-reactive bacterium. ACS Chem Biol 7:2074-2081. https://doi.org/10.1021/cb300383y

Chauhan PS, Goradia B, Saxena A (2017) Bacterial laccase: recent update on production, properties and industrial applications. 3 Biotech 7:1-20. https ://doi.org/10.1007/s13205-017-0955-7

Christopher LP, Yao B, Ji Y (2014) Lignin biodegradation with laccase-mediator systems. Front Energy Res 2:1-13. https://doi.org/10.3389/fenrg .2014 .00012

Cornish-Bowden A (1995) Analysis of enzyme kinetic data. Oxford University Press, New York

De la Torre M, Martín-Sampedro R, Fillat U, Eugenio ME, Blánquez A, Hernández M, Arias ME, Ibarra D (2017) Comparison of the efficiency of bacterial and fungal laccases in delignification and detoxification of steam-pretreated lignocellulosic biomass for bioethanol production. J Ind Microbiol Biotechnol 44:1561-1573. https://doi.org/10.1007/s10295-017-1977-1

Deschenes LA, Vanden Bout DA (2000) Origin 6.0: scientific data analysis and graphing software origin lab corporation (formerly Microcal Software, Inc.). J Am Chem Soc 122:9567-9568. https://doi.org/10.1021/ja004761d

Durao P, Chen Z, Fernandes AT, Hildebrandt P, Murgida DH, Todorovic S, Pereira MM, Melo EP, Martins LO (2008) Copper incorporation into recombinant CotA laccase from Bacillus subtilis: characterization of fully copper loaded enzymes. J Biol Inorg Chem 13:183-193. https://doi.org/10.1007/s0077 5-007-0312-0

Fernandes AT, Soares CM, Pereira MM, Huber R, Grass G, Martins LO (2007) A robust metallo-oxidase from the hyperthermophilic bacterium Aquifex aeolicus. FEBS J 274:2683-2694. https://doi.org/10.111 1/j.1742-4658.2007.05803.x

Fillat U, Ibarra D, Eugenio ME, Moreno AD, Tomás-Pejó E, Martín-Sampedro R (2017) Laccases as a potential tool for the efficient conversion of lignocelIulosic biomass: a review. Fermentation 3:17. https://doi.org/10.3390/ fermentation3020017

Hilgers R, Vincken JP, Gruppen H, Kabel MA (2018) Laccase/mediator systems: their reactivity toward phenolic lignin structures. ACS Sustain Chem Eng 6:2037-2046. https://doi.org/10.1021/acssuschemeng.7b03451

Kim HW, Lee SY, Park H, Jeon SJ (2015) Expression, refolding, and characterization of a small laccase from Thermus thermophilus HJ6. Protein Expr Purif 114:37-43. https://doi.org/10.1016/j.pep.2015.06.004

Kumari A, Kishor N, Guptasarma P (2018) Characterization of a mildly alkalophilic and thermostable recombinant Thermus thermophilus laccase with applications in decolourization of dyes. Biotechnol Lett 40:285-295. https ://doi.org/10.1007/s10529-017-2461-8
Liu H, Cheng Y, Du B, Tong C, Liang S, Han S, Zheng S, Lin Y (2015) Overexpression of a novel thermostable and chloride-tolerant laccase from Thermus thermophilus SG0.5JP17-16 in Pichia pastoris and its application in synthetic dye decolorization. PLoS ONE 10(3):e01 19833. https://doi. org/10.1371/journal.pone.0119833

Miller GL (1959) Use of dinitrosalicylic acid reagent for determination of reducing sugar. Anal Chem 31:426-428. https://doi.org/10.1021/ac60147a030

Miyazaki K (2005) A hyperthermophilic laccase from Thermus thermophiIus HB27. Extremophiles 9:415-425. https://doi.org/10.1007/s0079 2-005-0458-z

Moniruzzaman M, Ono T, Azmi Bustam M, Yusup S, Uemura Y (2015) Pretreatment of wood biomass with ionic liquids: a "green" approach to separate cellulose for use in oilfield application. J Appl Sci 15:531-537. https://doi. org/10.3923/jas.2015.531.537

Munk L, Sitarz AK, Kalyani DC, Mikkelsen JD, Meyer AS (2014) Can laccases catalyze bond cleavage in lignin? Biotechnol Adv 33:13-24. https://doi. org/10.1016/j.biotechadv.2014.12.008

Navas L, Amadío A, Fuxan I, Zandomeni R (2014) Identificación de genes codificantes de enzimas de interés industrial en una cepa de bacteria termofílica aislada de aguas termales de Salta (Argentina). RIA Rev Investig Agrop 40:46-53

Navas LE, Berretta MF, Ortiz EM, Benintende GB, Amadio AF, Zandomeni RO (2015) Draft genome sequence of Thermus sp. isolate 2.9, obtained from a hot water spring located in Salta, Argentina. Genome Announc 3:1-2. https://doi.org/10.1128/genomeA.01414-14

Oliva-Taravilla A, Tomás-Pejó E, Demuez M, González-Fernández C, Ballesteros M (2015) Inhibition of cellulose enzymatic hydrolysis by laccase-derived compounds from phenols. Biotechnol Progr 31:700-706. https://doi. org/10.1002/btpr

Oliva-Taravilla A, Tomás-Pejó E, Demuez M, González-Fernández C, Ballesteros M (2016) Phenols and lignin: key players in reducing enzymatic hydrolysis yields of steam-pretreated biomass in presence of laccase. J Biotechnol 218:94-101. https://doi.org/10.1016/j.jbiotec.2015.11.004

Outten FW, Huffman DL, Hale JA, Halloran TVO (2001) The Independent cue and cus systems confer copper tolerance during aerobic and anaerobic growth in Escherichia coli. J Biol Chem 276:30670-30677. https://doi. org/10.1074/jbc.M104122200

Ramalingam B, Sana B, Seayad J, Ghadessy FJ, Sullivan MB (2017) Towards understanding of laccase-catalysed oxidative oligomerisation of dimeric lignin model compounds. RSC Adv 7:11951-11958. https://doi. org/10.1039/C6RA26975C

Reiss R, Ihssen J, Richter M, Eichhorn E, Schilling B, Thöny-Meyer L (2013) Laccase versus laccase-like multi-copper oxidase: a comparative study of similar enzymes with diverse substrate spectra. PLoS ONE 8(6):e65633. https://doi.org/10.1371/journal.pone.0065633

Roberts SA, Wildner F, Grass G, Weichsel A, Ambrus A, Rensing C, Montfort WR (2003) A labile regulatory copper ion lies near the $\mathrm{T} 1$ copper site in the multicopper oxidase CueO. J Biol Chem 278:31958-31963. https://doi. org/10.1074/jbc.M302963200

Rodrigues J, Faix O, Pereira H (1998) Determination of lignin content of EucaIyptus globulus wood using FTIR spectroscopy. Holzforschung 52:46-50. https://doi.org/10.1515/hfsg.1998.52.1.46

Singh S, Shekher R, Sehgal S, Kamthania M, Kumar A (2011) Laccase: microbial sources, production, purification, and potential biotechnological applications. Enzyme Res. https://doi.org/10.4061/2011/217861

Thurston CF (2019) The structure and function of fungal laccases. Microbiology 140:19-26

Vila C, García A, Fillat A, Vidal T, Ariza J (2011) Use of thermogravimetric analysis to monitor the effects of natural laccase mediators on flax pulp. Bioresour Technol 102:6554-6561. https://doi.org/10.1016/j.biortech.2011.03.068

Yu H, Li X, Xing Y, Liu Z, Jiang J (2014) A sequential combination of laccase pretreatment and enzymatic hydrolysis for glucose production from furfural residues. BioResources 9:4581-4595

Zheng Z, Li H, Li L, Shao W (2012) Biobleaching of wheat straw pulp with recombinant laccase from the hyperthermophilic Thermus thermophilus. Biotechnol Lett 34:541-547. https://doi.org/10.1007/s10529-011-0796-0 